\title{
原腊論文
}

\section{利根川上流域の支川合流に伴う 河道唄留効果と計画高水流量の考察}

\section{土屋十图 1)}

\author{
1) 前橋工科大学工学部社会環境工学科 \\ （厂371-0816 群馬県前橋市上佐鳥町460-1）
}

近年，ダムによらない治水対策が課題となり，河川計画の検証が期待されている．1980年に利根川の治水計画は 当時の技術水準のもとに集中型モデルとして貯留関数法が使われた。1947年9月に来襲したカスリーン台風の当時は 基準点より上流にはダムは存在していない. 著者は既往研究に扔いて戦後のダム設置のもとにどのように治水安全 度が年々向上してきたのか，同モデルを使い検証してきた． 利根川は工事実施基本計画から 45 年が過ぎ，降雨掠よ び洪水デー夕の蓄積や流出モデルの開発が進み, 実際の洪水流出現象からより正確な検証が求められるようになっ た. 本研究では, 利根川上流域の支川合流に伴う河道貯留効果による低減効果について着目し, 貯留関数法, Kinematic wave法により洪水流出解析を行い, 同時に計画高水流量の考察を行った.

キーワード : 利根川上流域, 洪水流出解析, 計画洪水流量, 支川合流, 河道貯留効果

\section{I .はじめに}

利根川の治水計画（利根川水系工事実施基本計画） は，1947年9月洪水（カスリーン台風）を契機に昭 和24年に策定された「利根川改修改訂計画」の大綱 を引継ぎ，昭和40年に策定された。昭和55年（1980 年）には，カスリーン台風の洪水を主要な対象洪水 とし, さらに過去の降雨特性及び流出特性を検討し て，八斗島基準点における基本高水のピーク流量を $22,000 \mathrm{~m}^{3} / \mathrm{s}$, 計画高水流量 $16,000 \mathrm{~m}^{3} / \mathrm{s}$, とする計画 で全面改訂された（国土交通省関東地方整備局利根 川ダム統合管理事務所，2003）。更に，平成9年の河 川法改正により，上流ダム群による調節容量を5,500 $\mathrm{m}^{3} / \mathrm{s}$, 河道への配分容量を $16,500 \mathrm{~m}^{3} / \mathrm{s}$ に変更してい る。近年，㕕によらない治水対策が課題となり， これらの検証が期待されている。利根川の治水計画 は当時の技術水準のもとに集中型モデルとして貯留 関数法が使われた。 カスリーン台風の当時は基準点 より上流にはダムは存在していない。著者らは戦後 のダム設置のもとにどのように治水安全度が年々向 上してきたのか, 同モデルを使い検証してきた（中 村·土屋，2006)。また，淀川流域においても洪水 の安全性が年代ごとに向上してきた研究はすでに行
われている(佐山ら，2005).

利根川では工事実施基本計画から45年が過ぎ，降 雨および洪水データの蓄積や流出モデルの開発が進 み, 実際の洪水流出現象からより正確な検証が求め られている。本研究では, 利根川上流域の支川合流 に伴う河道貯留効果による低減効果について着目 し, 貯留関数法, Kinematic wave法により洪水流出 解析を行い, 計画高水流量の考察を加えた.

\section{II . 利根川上流域のダム群}

本研究の対象流域は標高 $1,834 \mathrm{~m}$ の大水上山を水 源とする利根川八斗島基準点より上流域である。総 延長 $140.5 \mathrm{~km}$, 流域面積 $5,150 \mathrm{~km}^{2}$, 平均勾配1/78で ある. 現在の稼働ダムは6基であり, ダム湖の流域 面積は全流域面積に対し26\%である。下久保ダム を除く5基の夕゙ム群は赤城連峰，榛名山，子持山な ど標高 $1,200 \sim 1,800 \mathrm{~m}$ の山々に囲まれた奥利根地域 に存在している。利根川上流域の主要な支川流域と ダム湖流域および残流域を図ー1に示した。 


\section{III. 対象降雨と降雨分布特性}

\section{1. 主要洪水時の雨量観測所数と流域平均雨量の 検定}

この研究で使用した降雨データは国土交通省及び 群馬県より収集した。解析対象の台風抢よび2日間 降雨量とこの時点のダム基数及び雨量観測所数を 表ー1に示した。1947年カスリーン台風時の雨量観 測所は11箇所，気象庁測候所の地上雨量計によるも のである。1959年伊勢湾台風時は26箇所であり，2 倍以上の設置数となり，以降，国，県などの雨量観 測所を含めて2005年現在では50箇所に達している。 なお，気象庁アメダスレーダー雨量計は1977年以降 であり, 本研究ではデー夕の統一性のため地上雨量 計の雨量を使用している。観測所の主要年ごとの設 置箇所を図一2に示す。これまでの雨量観測所，水 位観測所は戦後から現在まで，経済的かつ技術的な 背景をもとに, ダムの増設に伴い年々増加してきた。 これによって, 流域平均雨量の精度も向上している ことが考えられる。 そこで, 以降の解析を行う上で, 雨量観測所数の違いによる流域平均雨量の精度が各 検証年で異なってしまうことが推測される。これに より, 流域平均雨量の精度の誤差が流出解析を行う 際に大きく影響することが推察される。そこで，以 降の流出解析検討のために, 表一1に示した各検証 年とその時点の雨量観測所数の差から予測される精 度を検討する。

例えば，図一2に示すように1947年は雨量観測所 数は11箇所である。2005年には50箇所降雨観測所が ある. 2005年の場合，1947年と同一観測箇所の11箇 所を取り出した流域平均雨量と50箇所の降雨観測所 での流域平均雨量をt検定（5％有意水準）で比較 した。

また，同様に1959年の26箇所，1981年の37箇所， および1998年の43箇所についても同様の検討を行っ た。ただし，このとき必ずしも同一の雨量観測所が 存在しているとは限らず，また，同一の雨量観測所 であっても移設されていることが稀にあるため，そ の場合は最寄りの雨量観測所として扱うこととした.

その結果，すべて $5 \%$ の有意水準で境界值を満た し,さらに総降雨量でもその差が最大 $9.2 \mathrm{~mm}(5 \%)$ という結果を得た。よって, 本研究における各検証 年での雨量観測所数の相違による流出解析に及ぼす 影響は極めて低いと考えることができる。

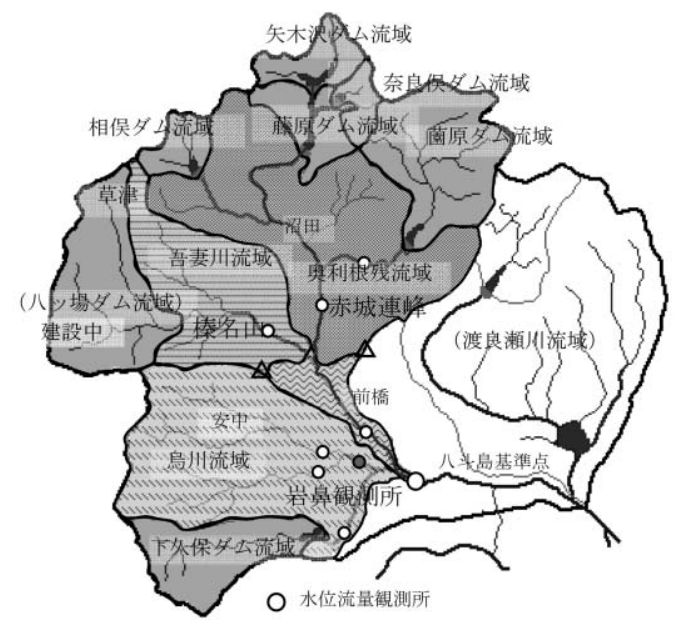

図-1 利根川上流域図

Fig. 1 Map of the Tone upper river basin.

表-1 主な台風とその当時のダム基数及び雨量観測

Table 1 Number of dams and rainfall stations on condition that of each rainfall events (Typhoon).

\begin{tabular}{l|c|c|c}
\hline \multicolumn{1}{c|}{ 台風 } & ダム数 & 雨量観測所数 & 2日間雨量 \\
\hline 1947年カスリーン台風 & 0基 & 11箇所 & $326.3 \mathrm{~mm}$ \\
1959年伊勢湾台風 & 2基 & 26箇所 & $195.7 \mathrm{~mm}$ \\
1981年台風第15号 & 5基 & 37箇所 & $229.1 \mathrm{~mm}$ \\
1998年台風第5号 & 6基 & 50箇所 & $187.3 \mathrm{~mm}$ \\
\hline
\end{tabular}

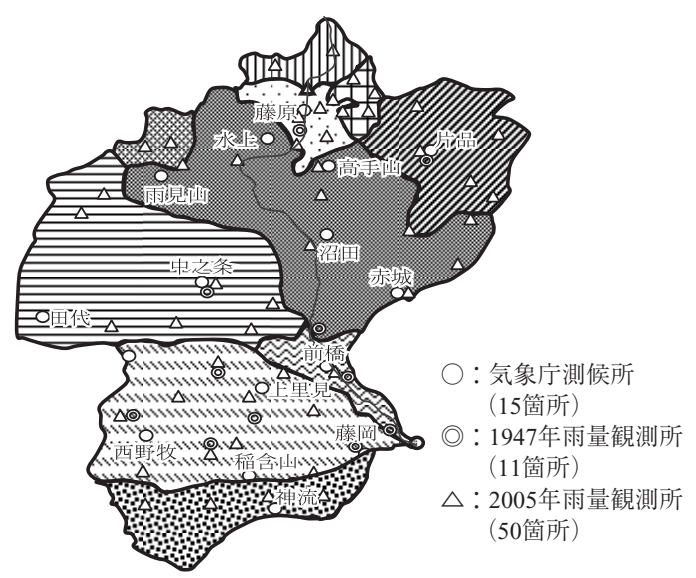

困-2 雨量観測所の配置図

Fig. 2 Map of rainfall observation points.

$\bigcirc$ : Weather stations of Meteorological agency (15 observation points).

(O) : Rain fall observation points in 1947 year (11 observation points).

$\triangle$ : Rain fall observation points in 2005 year (50 observation points). 


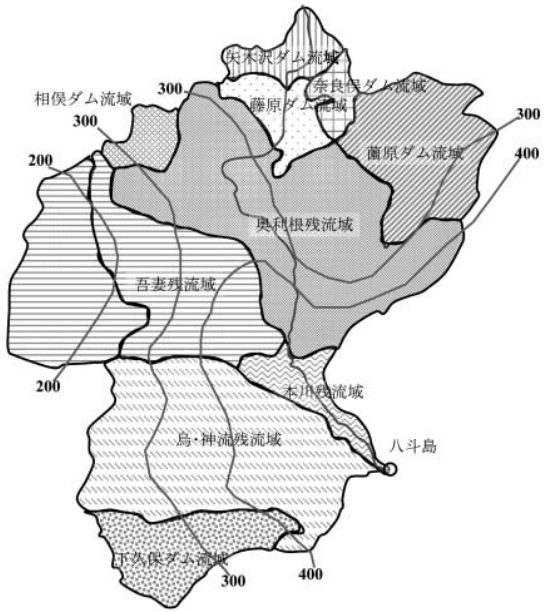

図－3 1947年カスリーン台風の2日間等雨量線

Fig. 3 Contour line of total rain fall by the Catherine Typhoon in 1947 year.

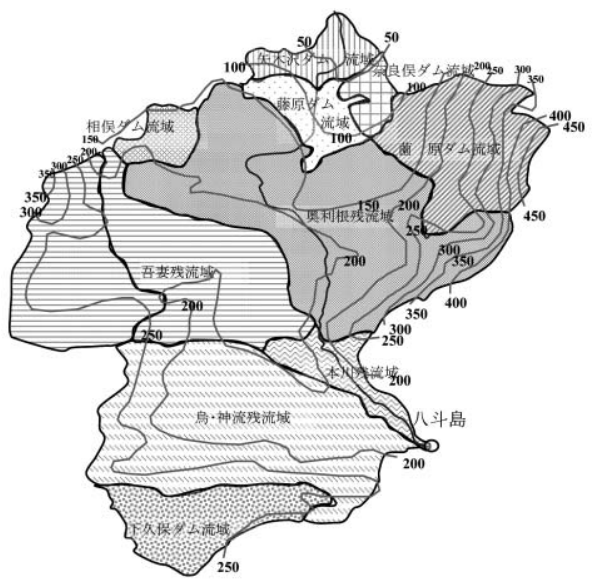

図－4 1959年伊勢湾台風の2日間等雨量線

Fig. 4 Contour line of total rain fall by the Ise bay typhoon in 1959 year.

\section{2. 洪水をもたらした降雨分布}

1） 1947 年カスリーン台風の降雨分布

各流域での総降雨量は奥利根流域で $273 \mathrm{~mm}$, 吾妻

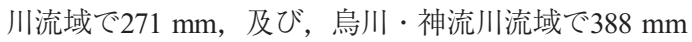
であった。利根川上流域では3日間で318 mmの雨が 降り，時間最大雨量は $31.5 \mathrm{~mm} / \mathrm{hr}$ であった。図一3 には2日間等雨量分布を示す。赤城山を中心とする 山地一帯で，おびただしい土砂流出が発生した（国 土交通省関東地方整備局利根川ダム統合管理事務 所，2003）。このときの八斗島基準点での洪水流出

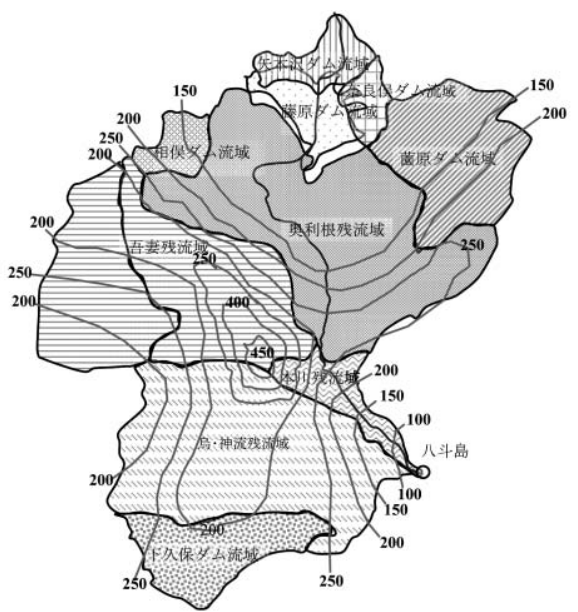

図－5 1981年台風第15号の2日間等雨量線

Fig. 5 Contour line of total rain fall by the fifteen typhoon in 1981 year.

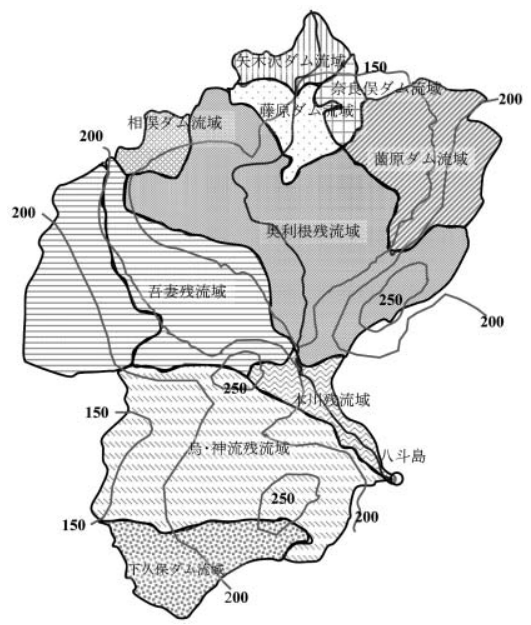

図－6 1998年台風第5号の2日間等雨量線

Fig. 6 Contour line of total rain fall by the fifth typhoon in 1998 year.

量は $16,850 \mathrm{~m}^{3} / \mathrm{sec}$ と推定され, 既往最大洪水量とし て記録されている（内務省関東土木出張所，1947）。 現在は，平成18年2月に策定された利根川水系河川 整備基本方針では基本高水 $22,000 \mathrm{~m}^{3} / \mathrm{s}$ ，計画高水流 量 $16,500 \mathrm{~m}^{3} / \mathrm{sec}$ に改定されている.

2）1959年伊勢湾台風の降雨分布

この伊勢湾台風は，昭和 9 年の室戸台風，昭和 20 年の枕崎台風に次ぐ, 観測史上で三番目の大型台風 であった。2日間等雨量分布図を図一4に示した。

各流域での総降雨量は奥利根流域で $178 \mathrm{~mm}$, 吾 
妻川流域で $250 \mathrm{~mm}$ ，及び，烏川・神流川流域では $224 \mathrm{~mm}$ であった。利根川上流域では3日間で $214 \mathrm{~mm}$ の降雨があり, 時間最大雨量は $14.4 \mathrm{~mm} / \mathrm{hr}$ であった。 また，このときの八斗島基準点での実測ピーク流量

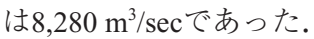

\section{3） 1981 年台風第15号の降雨分布}

1981年台風第15号の各主要流域での総降雨量は奥 利根流域で $198 \mathrm{~mm}$, 吾妻川流域で $321 \mathrm{~mm}$, 及び烏 川・神流川流域では2 $60 \mathrm{~mm}$ であった。利根川上流 域では3日間で $253 \mathrm{~mm}$ の降雨があり, 時間最大雨量 は13.4 mm/hrであった。また，このときの八斗島基 準点での実測ピーク流量は7,367 $\mathrm{m}^{3} / \mathrm{sec}$ であった。 2 日間等雨量分布図を図一5に示した。

\section{4）1998年台風第5号の降雨分布}

各流域での総降雨量は奥利根流域で169 mm, 吾妻 川流域で $189 \mathrm{~mm}$ ，及び，烏・神流川流域で204 mm であった。利根川上流域では3日間で $185 \mathrm{~mm}$ の雨が
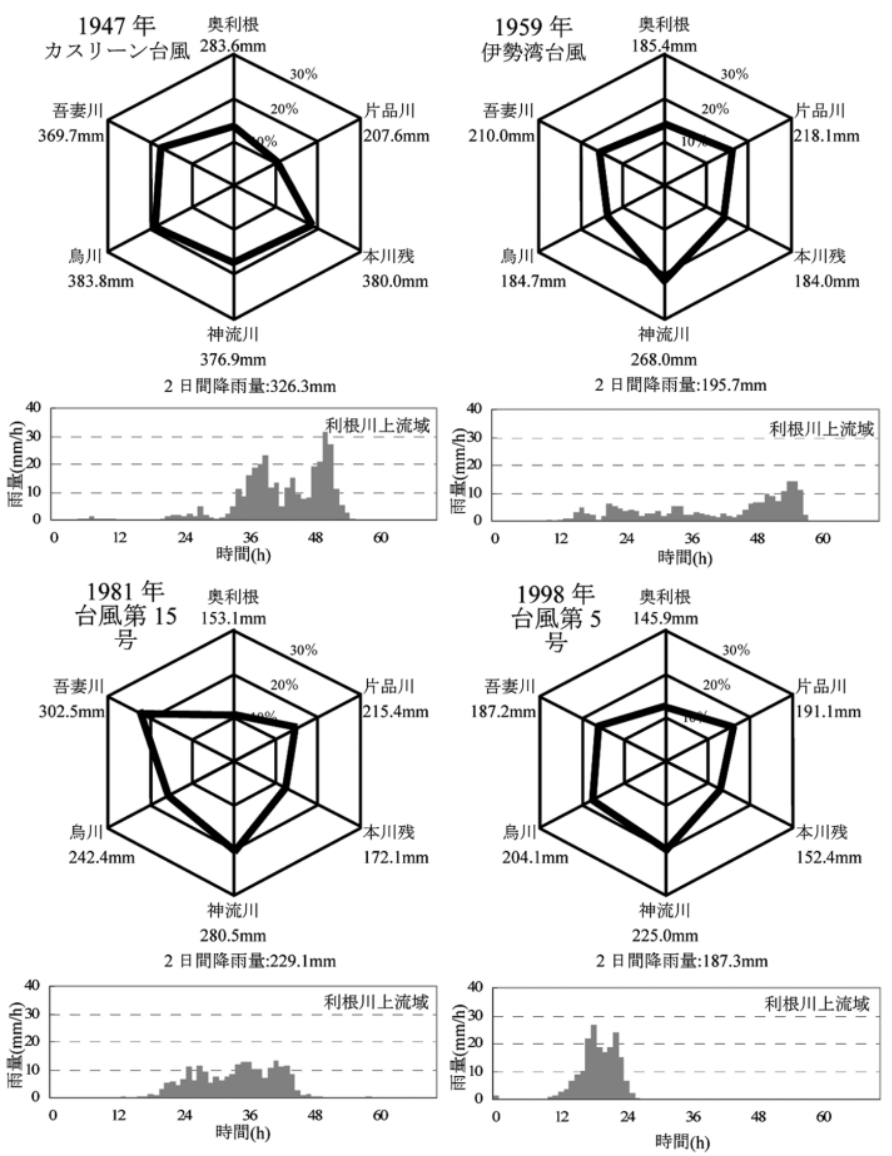

図-7 対象台風における2日間雨量比と利根川上流域のハイエトグラフ

Fig. 7 Rate of regional distributions at 2-days rain fall each typhoon events and hyetographs in the Tone upper river basin.
降り，時間最大雨量は $26.8 \mathrm{~mm} / \mathrm{hr} ゙$ あった。また， このときの八斗島基準点での実測ピーク流量は $9,770 \mathrm{~m}^{3} / \mathrm{sec}$ あった。2日間等雨量分布図を図一6 に示した。

\section{3. 降雨イベントの空間的分布特性}

利根川上流域は図ー1に示したように地形的にも 流出解析上の残流域を含む6つの小流域に区分する ことができる。本研究で対象とした降雨はその大部 分が2日間で終了しているため, 降雨解析期間を 2 日 間と設定した。各流域の降雨地域特性は2日間雨量 比として（1）式によって算出した.

$$
K_{n}=\frac{R_{n}}{\sum_{i=1}^{6} R_{i}} \times 100
$$

ここに, $K_{n}: n$ 流域の2日間雨量比 $(\%), \quad \sum_{i=1}^{6} R_{i}$ : 主要6流域の 2 日間雨量の総和 $(\mathrm{mm} / 2 \mathrm{days}), R_{n}: n$ 流
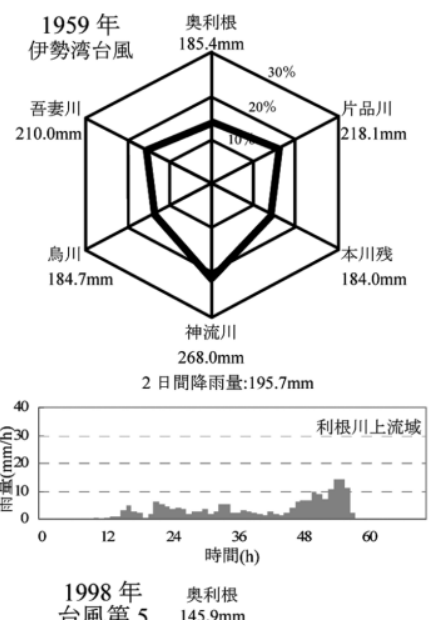

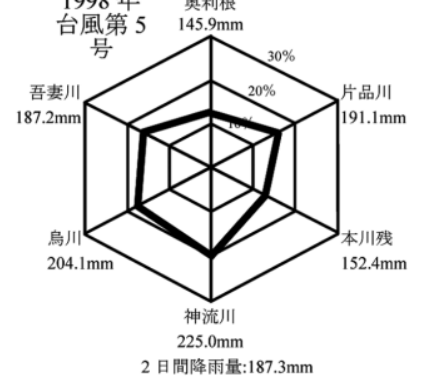


域の2日間雨量 $(\mathrm{mm} / 2$ days $), n$ : 主要流域である.

算出された2 日間雨量比によって流域別の降雨分 布図と利根川上流域のハイエトグラフを図ー7に示 した，総降雨量に占める流域別の割合が示されてい るへキサゴンの頂点に対象流域とその2日間雨量を 示し，その下に利根川上流域2日間雨量を示した。 1947年カスリーン台風の降雨は現在ダムのある奥利 根地域, 片品川流域には少なく, 本川残流域や烏川 流域に集中している。その後の主要なイベントも同 様に奥利根地域, 片品川流域には少なく, 吾妻川, 神流川流域に強い降雨が分布している。特に, 1947 年, 1981年, 1998年の強い雨域は赤城連峰, 榛名山 などの山麓斜面（残流域）に集中している.

このように, 実現象の降雨の空間分布は計画降雨 やダム配置で意図することと異なり地形的な要因が 推察される。地形と降雨分布に関する研究では, 山 田が大雨の分布形態と地形性の関係について検討 し, 流域平均雨量は前線の発達状態や台風の規模, 強さに支配されるが個々の地点の降雨量は気象擾乱 の性質と地形条件に強く依存することを指摘してい る(山田, 1985). 更に, 利根川流域を対象に地形 量による多雨度の推定を行い地形勾配, 風上側の高 い山岳を障害として, 観測所の標高, 山越えによる 降雨補正を計量化し500 m以上の地点では多雨度の 推定が可能であることを証明している(山田, 1985). また, Tasakaは強雨と地形の関係について, 四国地 方の雨量分布を調へ，時間雨量分布は特定の地域に 集中して現れないが，日雨量分布では山岳の南斜面 に強雨域が現れるとしている(Tasaka，1981)。こ れらの指摘は時間単位よりむしろ日単位分布の方が 地形との関係が強く, 大河川の洪水を考えるとき地 形と降雨分布の重要性を示唆している。一般に標高 が高くなるほど降雨量は増加するが, 高い山では多 雨地帯をこえると再び減少することが確認されてい る (Smallshaw, 1953). 以上の既往研究からも利根 川上流域の空間的降雨分布特性は地形的な効果が支 配しているものと考えられる。

\section{IV 。河道野留効果による低減効果}

\section{1. 基本高水の流量決定}

昭和 55 年に八斗島基準点における基本高水の流量 を22,000 $\mathrm{m}^{3} / \mathrm{s}$, 計画高水流量 $16,000 \mathrm{~m}^{3} / \mathrm{s}$, とする計 画で全面改訂されたが，このとき，既往最大洪水流 量あるいは $1 / 200$ 年の確率洪水のどちらか大きい方

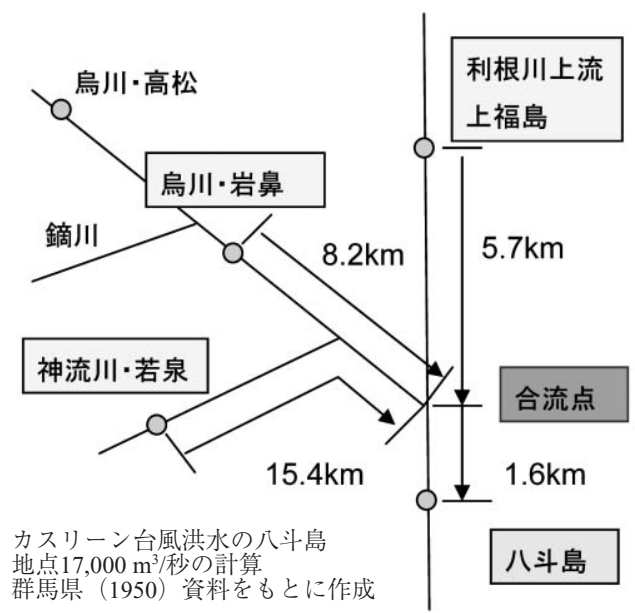

図-8 昭和24年の八斗島基準点における基本高水の設定 Fig. 8 Observation stations due to establish a basic high water level in the Yattajima standard point in 1949 year.

にすることとなった，治水計画に確率論の手法が取 り入れられた。

1947年9月のカスリーン台風の洪水時, 八斗島地 点では実測流量は観測されていなかったため, 利根 川本川と烏川合流点より本川上流5.7 kmの上福島観 測所, $8.2 \mathrm{~km}$ 上流の烏川・岩鼻観測所，および 15.4 $\mathrm{km}$ 上流の神流川・若泉観測所のハイドログラフか ら3河川の流量の算術的重社合わせを行い, 合流量 の最大值が $16,850 \mathrm{~m}^{3} / \mathrm{s}$ であるため八斗島地点のピー ク流量を $17,000 \mathrm{~m}^{3} / \mathrm{s}$ とした（建設省関東地方建設局, 1987)。その後，この数值は昭和 24 年の利根川改修 改訂計画および昭和40年までの利根川水系工事実施 基本計画の基本高水としてきた（図一8）。現在，平 成9年の河川法改正に伴い，平成18年2月に策定され た利根川水系河川整備基本方針では基本高水 22,000 $\mathrm{m}^{3} / \mathrm{s}$, 計画高水量 $16,500 \mathrm{~m}^{3} / \mathrm{s}$, に改定されている. 本研究では, これらの水理・水文学的な河川計画は 戦後の荒廃した国土環境や社会的背景, 即ち当時は 貯留関数法もない時代であり, 経験的な技術水準の もとにあり, その妥当性の有無を現在時点と比較し て評価するものではない.しかし, これに対して昭 和 25 年, 安芸は河川合流点では洪水量は調整されて 10〜20％少なくなることを指摘している（群馬県， 1950).

\section{2. 河道貯留効果に関する既往研究}

上記のように安芸が河川合流点では洪水量は調整 
されて減少することを示唆している。これは利根川 の八斗島基準点での流出解析では大変重要な視点で ある. 従って, 河道貯留効果について下記のように 検討する。なお，ここでは河道貯留効果は流域の河 道区間での河床の抵抗，支川合流による貯留などに より流下とともに洪水流の変形と伝播に影響を与え ることをいい，洪水が伝播し，ピーク流量が減少す ることを意味している。これらを河道貯留効果と考 える。

河川合流部の水理的研究は重要な研究課題とされ ていたが，高橋が河川合流部の洪水流の特性に関す る研究において, 独立支川と従属支川を区分して取 り扱い, 理論解析と水理実験を行っている. 即ち, 勾配の緩い大規模支川が流入する場合には支川流量 が小さい場合でも合流点における貯留効果は大き く, 支川流量が大きい場合には局所水理が本川洪水 に重大な影響を及ぼすとしている。更に，従属支川 は固有流量が非常に少ない場合, 本川洪水からの逆 流の貯留域となり, 固有流量の多い場合でも堰上げ によって固有流量が貯留され, 合流点での洪水流の 変形が大きいことを証明している（高橋，1972）. ここでは固有流量は洪水時以外の通常の平水流量を 意味している。

河川合流部の水理的研究は, 1980～1990年代にな り, 3次元乱流モデルによる河川合流部の流れ予測 (玉井・上田, 1987), 水理実験による河川合流部の 大規模渦構造と河床形状 (大本ら, 1992), おょび 河川合流部の洪水流と河床変動の非定常3次元解析 (福岡ら，1995)が行われた。このうち福岡ら (1995) の研究では検証区間の合流点までの距離が短く河道 の貯留効果を確認するまでに至っていない。高橋 (1972) は1次元的な検討ではあるが実用的視点から 理論解析と水理実験により合流による損失などの局 所的水理現象を考慮し合流点における貯留効果は大 きいことを上記のように明らかにした。本研究では 既往研究の成果を参考に洪水流出の実現象を洪水流 出解析により合流点における貯留効果を検証する.

\section{3. 洪水流出解析}

本研究では河道区間での洪水追跡モデルを導入し ない場合と, これを導入する場合に分けて検討した。 即ち, 前者は貯留関数法による集中型モデル, 後者 は斜面流がKinematic waveモデルと河道流が一次元 の不定流モデルを使用して, 観測地点での洪水ピー ク流量の誤差について検証する, 検証地点は, 本研
究の対象流域である利根川の治水計画の基準点であ

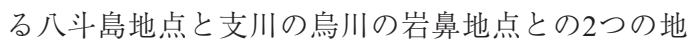
点で検証した。

なお，1998年台風5号の降雨・流出解析を貯留関 数法で解析を行った。この検討では各洪水イベント の流出計算は, 上流の6つのダムの流入・流出はダ ム操作規則に従っているものとして解析し, パラメー 夕の同定を行った (中村·土屋, 2006). この結果 はピーク流量, 立ち上がり逓増部は良く一致してい る。しかし, 派減部はあまり良い一致が見られない. このため斜面分割を細かくして物理性をもつ Kinematic waveモデルを追加して解析検討を行って いる.

ここで, 斜面の流出モデルであるKinematic wave 法を (4.1) 〜 (4.3) に示す.

・水深がA層厚を越えない場合

$$
\begin{aligned}
& \frac{\partial H(X, t)}{\partial t}+\frac{1}{B(X)} \frac{\partial}{\partial X}\{B(X) Q(x, t)\} \\
& =r_{e}(X, t) \cos \theta, 0 \leq X \leq L \\
& Q=\frac{k \sin \theta}{\gamma} H
\end{aligned}
$$

・水深がA層厚を越える場合

$$
Q=\frac{k \sin \theta}{\gamma} H+\frac{\sqrt{\sin \theta}}{N}(H-d)^{\frac{5}{3}}
$$

ここで, $\mathrm{X}$ : 斜面上端からの距離, $\mathrm{t}$ ：時間， $\mathrm{B}(\mathrm{X})$ : 斜面幅, $\mathrm{H}(\mathrm{X}, \mathrm{t})$ : 流れ方向に垂直にとった実質の 水深, $\mathrm{Q}(\mathrm{X}, \mathrm{t})$ : 単位幅あたりの流量, $\mathrm{r}_{\mathrm{e}}(\mathrm{X}, \mathrm{t})$ : 有効降雨強度, $\theta$ : 斜面勾配, $L$ : 流下方向に計った 斜面長, $\mathrm{d}$ : A 層厚, $\gamma$ : 有効間隙率, $N$ : 粗度係数 である。

また, 一次元河道解析は, MIKE11モデルを用い, 以下の連続の式 (4.4) および運動方程式 (4.5) に より計算を行う。

$$
\begin{aligned}
& \frac{\partial Q}{\partial x}+\frac{\partial A}{\partial t}=q \\
& \frac{\partial Q}{\partial t}+\frac{\partial\left(\alpha \frac{Q^{2}}{A}\right)}{\partial t}+g A \frac{\partial h}{\partial x}+\frac{g Q|Q|}{C^{2} A R}=0
\end{aligned}
$$

ここで, $Q:$ 流量 $\left(\mathrm{m}^{3} / \mathrm{s}\right), A$ : 流下断面積 $\left(\mathrm{m}^{2}\right)$, $q$ : 横流入量 $\left(\mathrm{m}^{3} / \mathrm{s}\right), h$ : 基準面からの高さ $(\mathrm{m})$, $C$ : シェジー抵抗係数, $R$ : 径深 $(\mathrm{m}), \alpha$ : 運動量の 
分布に関する係数とする.

次に，貯留関数法による木村（1961）の式を （4.6）～(4.8）に示した. 非線形の運動の式（4.6） を時系列の連続式 (4.7) に当てはめ, 降雨から洪 水流出を計算させる。

$$
\begin{aligned}
& S=K \cdot q^{p} \\
& r_{\text {ave }}-q=\frac{d S}{d t} \\
& T_{l}=0.0506 L^{-0.31}
\end{aligned}
$$

ここに, $r_{a v e}$ : 流域平均雨量 $(\mathrm{mm} / \mathrm{h}), q$ : 河道へ の流出高 $(\mathrm{mm} / \mathrm{h}), S:$ 降雨の貯留高 $(\mathrm{mm}), K, p$ : モデルパラメータ， $T_{l}$ : 遅滞時間 $(\mathrm{h}), L$ : 流域を 代表する河川延長 $(\mathrm{km})$.

\section{4. 流出モデルの再現性とパラメータ}

1) Kinematic wave法のパラメータ

斜面の流出モデルであるKinematic wave法に関し ては下記のように検討した。この解析での流域の事 例として利根川支川の烏川流域の検討結果を示す。 検証地点は岩鼻観測所としている。鳥川流域を57分 割し，それぞれの分割斜面に，最寄りの雨量観測所 の降雨を与えた。同様の方法で，烏川流域の支川で ある碓水川流域では80分割の斜面分割を行い, 同様 に鏑川流域では98分割の斜面分割を行い，追跡計算 を行っている。また，A層厚dは文献值を参考に， 市街地で $15 \mathrm{~cm}$, 山地で $30 \mathrm{~cm}$, A層の有効間隙率 $\gamma$ は市街地で0.2, 山地で0.3とした（土木学会，2002）。 モデルパラメータは, 流出係数 $\mathrm{f}$ と Manningの粗度

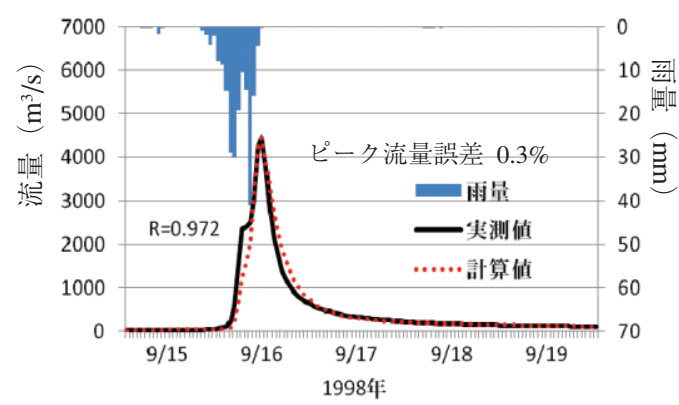

図－9 1998年降雨における同定結果（岩鼻地点）

Fig. 9 Results of identified simulation at Iwahana station by the rain fall event in 1998.
係数Nである（石森・土屋2008）。流出係数 $\mathrm{f}$ は, 実 降雨に対する直接流出分の割合としている. 図一9, 10には岩鼻観測所での1998年と2007年の計算によ る流出波形と実測波形を示す。図一11に地域ごと のManningの粗度係数 $\mathrm{N} の$ 同定結果を示す. Nは0.1 0.8 となり，すべての降雨イベントで同じ区域では ほぼ同じ值となった。特に，図ー11の(1)，(2)，(3) の山林部で $0.6 \sim 0.8$, (4), (5), (6)の平地部で $0.1 \sim 0.3$ となった。この值は水理公式集の記載の值の範囲内 であることから妥当な值であるといえる(土木学会, 1985).

一方，fは流域ごとに異なる值としたが，降雨イ ベント毎に $0.8 \sim 1.0$ となり 0.1 程度の違いが生じ，一 定の值で同定することができない。流出係数は，土 地利用の状況や降雨波形，降雨規模により変化する ことから流域別だけでなく, 土地利用や降雨を考慮 した分類が必要である。計算值と実測值の流出波形 は，すべて比較的良い一致がみられ，高い再現性が 得られたと考えられる。な抏，相関係数は0.972〜

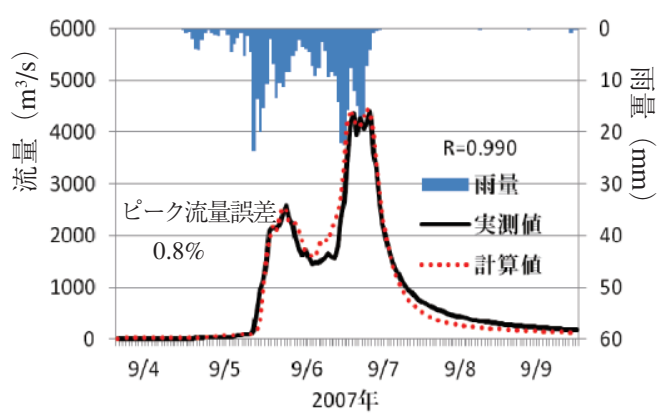

図－10 2007年降雨に扮ける同定結果（岩鼻地点）

Fig. 10 Results of identified simulation at Iwahana station by the rain fall event in 2007 .

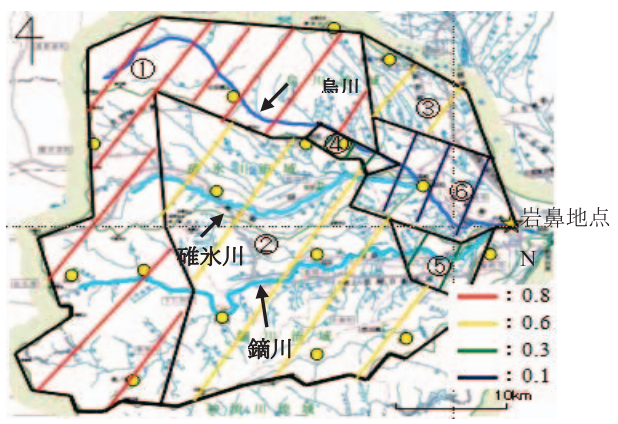

図-11 烏川流域の地域別のManningの粗度係数N

Fig. 11 Manning's Coefficient of roughness each region in the Karasu river basin. 
表－2 1998年台風5号による流出解析に用いた利根川の各流域におけるパラメータ

Table 2 An identified model parameters of each branch river basin and dams using run-off analysis with Tphoon No.5 in 1998 at the Tone river.

\begin{tabular}{|c|c|c|c|c|c|c|c|}
\hline 大分類流域 & 小分類流域 & $\begin{array}{c}\text { 流域面積 } \\
\mathrm{km}^{2}\end{array}$ & 定数 k & 定数 p & $\begin{array}{c}\text { 1次流出率 } \\
f_{1}\end{array}$ & $\begin{array}{c}\text { 飽和流出率 } \\
f_{s a}\end{array}$ & $\begin{array}{c}\text { 飽和雨量 } \\
R_{s a}(\mathrm{~mm})\end{array}$ \\
\hline \multirow[t]{12}{*}{ 奥利根流域 } & 藤原ダム流域（流入） & \multirow{2}{*}{ 133.7.0 } & 12.0 & 0.6 & 0.5 & 1 & 100 \\
\hline & 藤原ダム流域（放流） & & 12.0 & 0.9 & 0.6 & 0.65 & 50 \\
\hline & 相俣ダム流域（流入） & \multirow{2}{*}{112.6} & 16.5 & 0.6 & 0.45 & 1 & 150 \\
\hline & 相俣ダム流域（放流） & & 9.0 & 0.9 & 0.5 & 0.5 & 75 \\
\hline & 薗原ダム流域（流入） & \multirow{2}{*}{496.6} & 25.0 & 0.6 & 0.5 & 1 & 150 \\
\hline & 薗原ダム流域（放流） & & 10.0 & 0.97 & 0.35 & 0.8 & 80 \\
\hline & 矢木沢ダム流域（流入） & \multirow{2}{*}{169.0} & 18.0 & 0.6 & 0.5 & 0.8 & 50 \\
\hline & 矢木沢ダム流域（放流） & & 8.0 & 0.75 & 0.15 & 0.2 & 150 \\
\hline & 奈良俣ダム流域（流入） & \multirow{2}{*}{95.3} & 24.0 & 0.6 & 0.4 & 0.7 & 50 \\
\hline & 奈良俣ダム流域（放流） & & 15.0 & 1.3 & 0.15 & 0.15 & 80 \\
\hline & 片品川残流域 & 146.4 & 19.0 & 0.6 & 0.4 & 1 & 100 \\
\hline & 奥利根残流域 & 677.2 & 19.0 & 0.6 & 0.5 & 1 & 150 \\
\hline 本川残流域 & 本川残流域※ & 144.1 & 16.6 & 0.6 & 0.8 & 1 & 50 \\
\hline 吾妻川流域 & 吾妻川流域 & 1359.0 & 35.0 & 0.6 & 0.6 & 1 & 200 \\
\hline \multirow[t]{5}{*}{ 烏川·神流川流域 } & 下久保ダム流域（流入） & \multirow{2}{*}{326.5} & 21.0 & 0.6 & 0.25 & 1 & 130 \\
\hline & 下久保ダム流域（放流） & & 10.0 & 0.9 & 0.3 & 0.3 & 100 \\
\hline & 烏川·碓水川流域 & 742.5 & 12.0 & 0.6 & 0.5 & 1 & 300 \\
\hline & 鏑川流域 & 627.4 & 12.0 & 0.6 & 0.5 & 1 & 300 \\
\hline & 神流川残流域（勅使河原） & 119.7 & 18.0 & 0.6 & 0.55 & 1 & 150 \\
\hline
\end{tabular}

0.990 と高い值となり，ピーク流量誤差は $0.3 \sim 0.8 \%$ と なっている. 以上の検討結果からパラメータの決定 を行い, 流出モデルの再現性があるものと判断した.

\section{2) 貯留関数法のパラメータの同定}

パラメータを同定するにあたり，図一1にも示し た利根川上流域を主に6つのダム流域, 奥利根残流 域, 片品川残流域, 吾妻川流域, 本川残流域, 烏 川・碓水川流域, 鏑川流域, 神流川流域, 及び神流 川残流域に分割した。また，パラメータの同定には できる限り実測流量值を用い, 既往研究を参考に, 妥当性を考慮しながら決定した。1998年の同定結果 を図ー12に示した。実測值と計算值の相関性は強 く，立ち上がり部とピークは良い再現性が認められ るが, 逓減部において良い一致が認められなかった。 また，(4.9)式(建設省河川局，1997)により実測值 と計算值の誤差が 0.03 以下となるように調整を行っ ている。

$$
E=\frac{1}{N} \sum_{i=1}^{N}\left\{\frac{Q_{0}(i)-Q_{c}(i)}{Q_{0 p}}\right\}^{2}
$$

ここに, $E$ : 誤差, $Q_{0}(i): i$ 時の実測流出量, $Q_{c}(i): i$ 時の計算流出量, $Q_{0 p}:$ 実測の最大流出量, $N$ : 計算時間数. を示す.

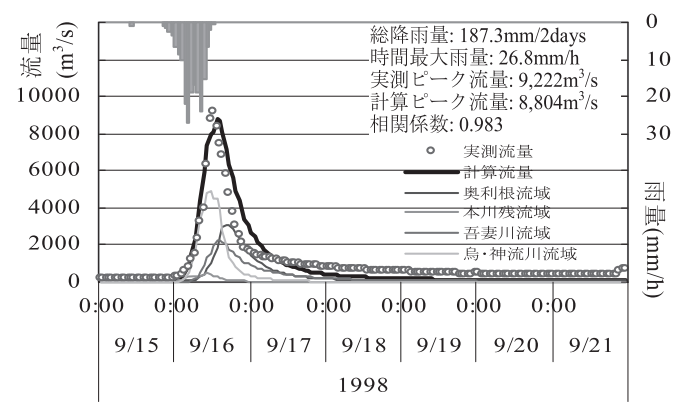

図－12 利根川上流域における同定結果（1998年）

Fig. 12 Simulation of an identified hydrograph by a case of rain fall event in 1998 in the Tone upper river basin.

この解析における同定結果のパラメータの一覧を 表一2に，ハイドログラフを図一12に示した。

1998年は実測ピーク流量と計算ピーク流量のピー ク差 $-420 \mathrm{~m}^{3} / \mathrm{s}$, 相関係数 0.983 および誤差 $\mathrm{E}=0.004$, である、計算值の聥減は遅い結果となった。しかし， ピーク流量の誤差1\%以内，波形の誤差も小さいこ とからパラメータの同定は妥当なもと考えられる。 また，八斗島基準点における各支川の流出の影響は， ハイドログラフの立ち上がりは，烏川・神流川流域 


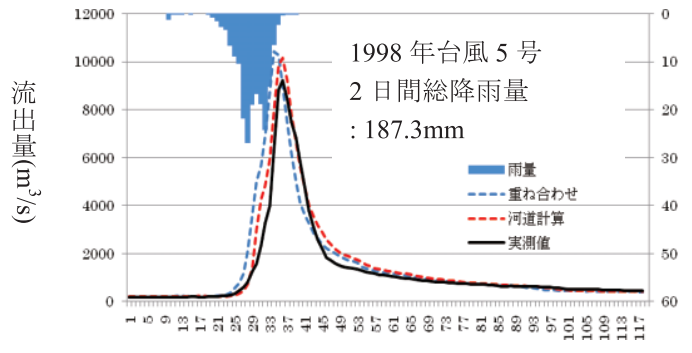

図-13 八斗島基準点におけるピーク流量の検証

Fig. 13 Hydrograph in the yattajima standard point due to verify of peek discharges at 1998 year in fifth typhoon.

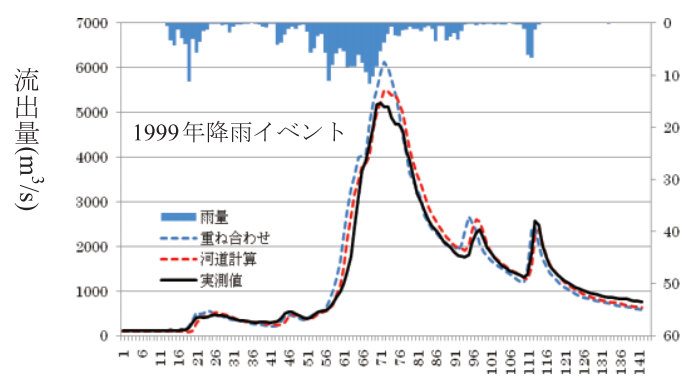

図-14 八斗島基準点におけるピーク流量の検証

Fig. 14 Hydrograph in the yattajima standard point due to verify of peek discharges by rain fall event in 1999 year.

で大きく，流量ピークが吾妻川流域で更に，聥減部 の影響は奥利根流域の洪水による影響が強いことが わかった。 なお，貯留関数法のダム放流に関するパ ラメータの設定は次のように行った。ダム操作は既 定操作マニュアル（洪水調節図）に沿ってダムを運 用しているが，降雨予測や水資源確保の観点から， 必ずしも洪水調節図と同様の操作が行えるとは限ら ない. 実測の放流量は経験的な判断を加えて決定さ れた放流量であると言われている。この研究では, 洪水調節図の放流量を対象に同定を行っている.

\section{5. 検証結果}

検証方法は，4.(1) 基本高水の流量決定で記述し たように各合流部では計算流量を，算術的に重ね合 わせたもの（以下「重㸚合わせ法」という）と一次 元河道モデルで流下時間を考慮して計算したもの （以下「河道計算法」）とし, 検証地点の実測値を比 較した。利根川の八斗島地点の場合, 検証対象洪水 は降雨・水位データの精度の高い最近の実測值とし た。検証降雨イベントはモデルパラメータの同定時
表-3 重ね合わせ法と河道計算法のピーク流量の比較 $\left(\mathrm{m}^{3} / \mathrm{s}\right)$

Table 3 Compare a simple accumulated method with calculation of channel flow method for peak discharges $\left(\mathrm{m}^{3} / \mathrm{s}\right)$.

\begin{tabular}{l|r|r|r}
\hline & \multicolumn{1}{|c|}{ 1998年 } & \multicolumn{1}{c|}{ 1999年 } & \multicolumn{1}{c}{ 2001年 } \\
\hline (1)重ね合わせ法 & 10,414 & 6,131 & 6,788 \\
(2)河道計算法 & 10,160 & 5,494 & 5,870 \\
実測值 & 9,222 & 5,202 & 6,785 \\
(1)と(2)の差 & 254 & 637 & 918 \\
減少割合 (\%) & 2.44 & 10.38 & 13.52 \\
相関係数 (重ね合わせ) & 0.900 & 0.979 & 0.971 \\
相関係数 (河道計算) & 0.987 & 0.993 & 0.994 \\
\hline
\end{tabular}

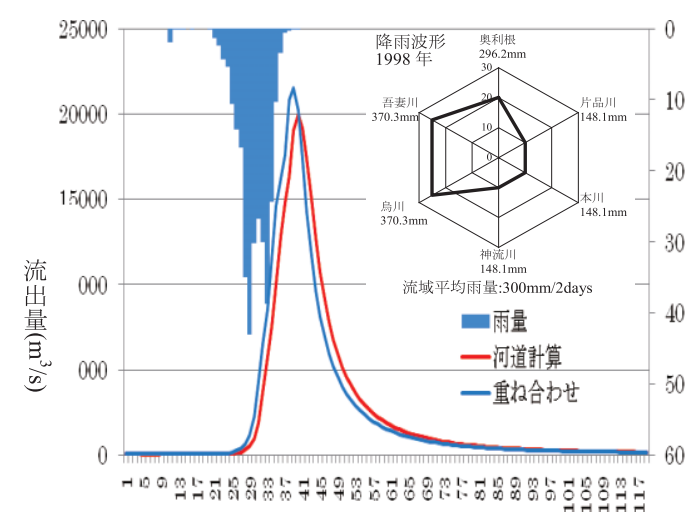

図－15 1998年降雨型1/165超過確率降雨よる流出予測

Fig. 15 Simulation of hydrograph by a case of rain fall event in 1998 year type at the Yattajima standard point under an exceed provability rain fall of 1/165.

に対象降雨とした3つの降雨イベント（台風 5 号1998 年，1999年，2001年）の実測值を使用した。解析結 果を図ー13〜14に示す。すべての降雨イベントに 対して，河道計算法では重ね合わせ法よりピーク流 量が減少している。しかし, その減少割合は岩鼻地 点の場合と同様に，降雨イベント別で $2.4 \% \sim 13.5$ \%と幅広い結果となった (表一 3 )。検証地点の実測 值と河道計算のピーク流量を比較すると1999年降雨 イベントは，ほぼ一致するが，他の $2 つ$ 降雨は10％ 以上の誤差が認められる。

次に, 超過確率降雨に対する流出解析予測を行っ た。解析に用いた降雨はカスリーン台風時の降雨量 に相当する流域平均降雨量 $300 \mathrm{~mm} / 2$ day, 超過確率 1/165を疑似降雨として与え, かつ流域別の降雨分 布は図一7をもとに，ダムのない吾妻川・烏川流域 および奥利根残流域の 2 日間雨量比を大きくし，降 雨波形は1998年の台風 5 号時の中央集中型の降雨を 
$300 \mathrm{~mm} / 2$ dayに引き延ばし, 重ね合わせ法と河道計 算法の解析を行った。疑似降雨によるシミレーショ ン結果は図ー15のようになり, 河道貯留効果によ る低減効果は $10 \%$ 程度である. 現在の6基のダムが 完成している現状でもピーク流量は $19,969 \mathrm{~m}^{3} / \mathrm{s}$ とな り, 河道貯留効果を考慮しても利根川の計画高水流 量 $16,500 \mathrm{~m}^{3} / \mathrm{s}$ 上回ることがわかった.

\section{V. 結論}

カスリーン台風以降の主要な洪水をもたらした過 去4つの降雨イベントの2 日間等降雨分布から利根川 上流域の空間的な降雨分布は地形的・地理的な特性 が示唆される。しかし, 降雨の空間分布は多様であ り, あらゆる降雨パターンを想定した解析が重要と なる。また，利根川上流域の支川合流に伴う八斗島 地点, 支川の烏川 - 岩鼻地点の洪水流出解析の結果, 河道の貯留効果の検討では, 重敉合わせ法と河道計 算法の比較検討から河道貯留効果は概ね $2.4 \%$ $13.5 \%$ 程度が期待される. 更に, カスリーン台風と 同規模の総降雨量でも降雨の空間分布が異なれば, 八斗島基準点で, 現在の計画高水流量を上回ること が推定される。

\section{謝辞}

本研究は, 資料の提供を国土交通省利根川ダム統 合管理事務所，および群馬県河川課より提供頂きま した。ここに改めて感謝を致します。また，当時の 大学院生栗原大輔君（現在, JR東日本旅客鉄道 (株) 首都圈本部）及び中村要介君（現在, 三井共同建設 コンサルタント(株)らの研究協力があったことをこ こに追記し，感謝いたします。

\section{引用文献}

土木学会 1985. 水理公式集. 技報堂出版 ; 163, 287, 288. 土木学会 2002. 水理公式集例題プログラム集. 土木学会 ; 203. 福岡捷二.五十嵐崇博 - 西村達也・宮崎節夫 1995. 河川合流 部の洪水流と河床変動の非定常三次元解析. 水工学論文集 $39: 435-440$.

群馬県 1950. カスリーン颱風の研究, 利根川水系に於ける災 害の実相. 日本学術振興会群馬県災害対策特別委員会報告; 288-443.

石森久仁子・土屋十图 2008. 出石川流域における洪水流出予 測と2004年台風23号時出水時の汇濫解析. 水工学論文集 $52: 817-822$.

建設省関東地方建設局 1987. 利根川百年史. 建設省関東地方 建設局；906-909.

建設省河川局 1997. 建設省河川砂防技術基準（案), 調査編. 技報堂出版；85-86.

木村俊晃 1961. 貯留関数による洪水流出追跡法. 建設省土木 研究所 ; 1-290.

国土交通省関東地方整備局利根川ダム統合管理事務所 2003. 業務のあらまし. 国土交通省関東地方整備局利根川ダム統合 管理事務所；1-25.

内務省関東土木出張所 1947. 昭和二十二年九月洪水報告書. 内務省関東土木出張所; 36.

中村要介・土屋十图 2006. ダムの増設に伴う利根川八斗島基 準点における治水効果の検討. 水工学論文集 50 : CD-ROM. 発表番号61.

大本照憲・平野宗夫・天野光歩・松尾 誠 1992. 河川合流部の 大規模渦構造と河床形状. 水工学論文集 $36: 373-378$.

佐山敬洋・立川康人・寶 馨・市川 温 2005. 広域分布型流出 予測システムの開発とダム群治水効果の評価. 土木学会論文 集 803/II-73：13-27.

Smallshaw J. 1953. Some precipitation-altitude studies of the Tennessee Valley Authority. Transaction of American Geophysical Union 34: 583-588. doi=10.1.1.106.893\&rep= rep1\&type=pdf.

高橋 保 1972. 河川合流部における洪水流の特性に関する研究. 京都大学防災研究所年報 15B: 371-383.

玉井信行・上田 悟 1987. 乱流モデルによる河川合流部の流れ の予測. 水理講演会論文集 $31: 437-442$.

Tasaka I. 1981. A case study of distribution of heavy rainfall caused by typhoon. The Science Reports of the Tohoku University 7th Series, Geography 31: 172-179.

山田啓一 1985. 大雨の分布形態と地形量の関係について. 水 理講演会論文集 $29 ： 197-202$.

（受付：2011年3月1日，受理：2011年6月9日） 


\title{
A Study of Effect of Channel Storage and Design Flood Discharge with Branch River Junction in the Upper Tone River Basin
}

\author{
Mitsukuni TSUCHIYA 1)
}

1) Department of Civil and Environmental Engineering, Maebashi Institute of Technology

(460-1, Kami Satori-cho, Maebashi, Gunma 371-0816 Japan)

Recently, a main subject of flood control measurement does not depend on dams. In the Tone river, inspection of design flood discharge is expected. Storage function method, one of the lumped rainfall-runoff models, has been used for flood control planning as a technical standard in Japan. When Catherine Typhoon attacked in 1947, there were no dam reservoirs in the upper stream of Yattajima standard point of observation, and also hydrological data were not sufficient. Based on the analysis of storage function model, we have checked how the flood risk has been reduced by dam construction work after the World War II. In this study, runoff analysis was carried out using large rainfall events which included Catherine Typhoon, and also effect of channel storage with branch river junction was estimated. The results can be summarized as follows. Rainfall distribution is influenced by geomorphologic characteristics, and then it is necessary to consider the spatial distribution of rainfall in the runoff analysis. Comparing with the peak discharge and total amount of discharge at the confluence point computed by 1D models, the effect of channel storage can be quantitatively estimated.

Key words : upper Tone river basin, flood runoff analysis, design flood discharge, branch river junction, storage effect of river channel 